\title{
Continental-scale spatial distribution, sources, and health risks of heavy metals in seafood: challenge for the water-food-energy nexus sustainability in coastal regions?
}

\author{
Jian Lu ${ }^{1,2,3}$ (D) Yichen Lin ${ }^{1,2} \cdot$ Jun $\mathrm{Wu}^{2} \cdot$ Cui Zhang ${ }^{1}$ \\ Received: 30 July 2020 / Accepted: 30 November 2020 \\ (C) The Author(s), under exclusive licence to Springer-Verlag GmbH, DE part of Springer Nature 2021
}

\begin{abstract}
Rare information on the seafood safety and the coastal water-food-energy nexus sustainability in terms of seafood safety is available. This study investigated the distribution of heavy metals in 3 kinds of seafood (bivalve molluscs, fish, and crustaceans) collected from coastal areas along the 18,000 km coastline of China. Risk assessment and source apportionment of heavy metals, and the coastal water-food-energy nexus sustainability in terms of heavy metal pollution were also performed. The results showed that total concentrations of 8 heavy metals $(\mathrm{Cu}, \mathrm{Pb}, \mathrm{Zn}, \mathrm{Cd}, \mathrm{Cr}, \mathrm{Hg}, \mathrm{As}$, and $\mathrm{Ni}$ ) in seafood varied with sampling sites and species by following the order of bivalve molluscs $>$ crustaceans $>$ fish. Estimated daily intake (EDI) analysis indicated that it was safe for humans to consume seafood in all sampling sites. Non-cancer risks posed by heavy metals were acceptable for $99.1 \%$ of adult and $97.7 \%$ of children. However, $\mathrm{Cr}$ and As in $72 \%$ of fish samples caused high cancer risks for children. The farmed fish posed relatively low risk in comparison with the wild fish suggested that it might be safer to consume farmed fish than wild fish. Source apportionment demonstrated that the fossil energy consumption (coal combustion and vehicle exhaust), seawater, and metallurgic dust might serve as the possible main sources of heavy metals in seafood. Based on the policy scenario analysis, the fossil-energy-controlling policy and clean coastal water action were beneficial to the seafood safety by reducing target heavy metals in seafood. These findings provided comprehensive information on seafood safety and the water-food-energy nexus sustainability in coastal regions at continental-scale in terms of heavy metal pollution.
\end{abstract}

KeywordsWater-food-energy nexus $\cdot$ Heavy metal $\cdot$ Seafood safety $\cdot$ Health risk $\cdot$ Source apportionment $\cdot$ Mariculture $\cdot$ Coastal zone

\section{Introduction}

Seafood, the important source of protein and other essential nutrients such as omega-3, fatty acids, and vitamins for coastal

Responsible editor: Vedula VSS Sarma

Jian $\mathrm{Lu}$

jlu@yic.ac.cn

1 CAS Key Laboratory of Coastal Environmental Processes and Ecological Remediation, Yantai Institute of Coastal Zone Research (YIC), Chinese Academy of Sciences (CAS); Shandong Key Laboratory of Coastal Environmental Processes, YICCAS, Yantai 264003, Shandong, People's Republic of China

2 University of Chinese Academy of Sciences, Beijing 100049 , People's Republic of China

3 Center for Ocean Mega-Science, Chinese Academy of Sciences, 7 Nanhai Road, Qingdao 266071, People's Republic of China residents, has been increasingly consumed by humans (Bosch et al. 2016; Zhong et al. 2018). Global seafood production reached 107.9 million tons in 2016 with $73.4 \%$ of catch yield and $26.6 \%$ of aquaculture yield (FAO 2018). China is the topranking fishing country and the main seafood exporter in the world with annual exporting seafood of 3,458,000 t (FAO 2018; BFMA 2019). Accordingly, annual seafood consumption in coastal area of China reached $61.5 \mathrm{~g} /$ day per capita in 2015 (Zhao, 2016).

Various contaminants can be accumulated in the seafood through the food chain (Storelli 2008; Zhu et al. 2014). Toxic pollutant residues in seafood especially the edible tissues will exert the potential health risk to the humans by frequent consumption (Loaiza et al. 2018). Coastal regions are undergoing various issues including extraordinarily rapid development of marine resource exploitation, sharp increase in populations, and the extensive impact of anthropogenic activities (Backer et al. 2019; Lu et al. 2018; Lu et al. 2019). Aquaculture 
industry and oceanographic engineering in the coastal regions have been damaging the offshore ecosystem due to discharge of industrial effluent and domestic sewage (Bertocci et al. 2019; Lu et al. 2020; Zhang et al. 2020). Heavy metals, stable in the aquatic environments, can be assimilated and accumulated in organisms to cause potential hazard so as to attract global attention (Chen et al. 2014; Huang et al. 2018). Heavy metals have been frequently detected in various regular food and seafood (Copat et al. 2013; Liao and Yang 2020; Rai et al. 2019; Varol et al. 2017). Excessive intake of heavy metals could pose potential risk to human health (Xing et al. 2020). Potential health risks of heavy metals could be estimated by a series of models with corresponding thresholds capable of determining the risk levels (USEPA 2004; Wen et al. 2019). Source apportionment of heavy metals is always a hot issue, and some quantitative methods such as positive matrix factorization (PMF) model (USEPA 2014; Guan et al. 2019) and isotopic fingerprints (Phillips and Gregg 2003; Zurbrick et al. 2013) have been widely used to determine contributions of the potential pollution sources.

Seafood is the important dietary components for the coastal populations. The coastal environments have been polluted by various pollutants with high ecological-health risks due to the rapid industrialization and urbanization in coastal regions. The risks of consuming seafood obtained from a bay or a coastal city in terms of heavy metals were evaluated (Chen et al. 2014; Fakhri et al. 2018; Li and Gao 2014). However, no comprehensive information is available to answer whether it is safe to frequently consume seafood in the coastal regions at national or continental scale. Issues regarding effects of pollution control measures on reducing risks of heavy metals in seafood have not been investigated. China possesses one of the longest coastlines $(18,000 \mathrm{~km})$ in the world so that the climate and species in various coastal zones of China are significantly different. Coastal regions are critical for social sustainability all over the world, especially for China since coastal regions contain $40 \%$ of population and $65 \%$ of GDP in China. (Lu et al. 2018). Therefore, seafood safety deserves more attention due to its importance for human well-beings in coastal regions of China.

Water-energy-food nexus is a useful tool for water and energy management (Al-Saidi and Elagib 2017; Mahjabin et al. 2020). Water network is related to food and energy network for comprehensive evaluate the environmental policy and impact (Al-Saidi and Elagib 2017; Mahjabin et al. 2020). More attention is generally paid to issues regarding consumption and production in water-energy-food nexus (Leivas et al. 2020; Smidt et al. 2016) while food safety analysis using water-energy-food nexus is scarce. The water-energy-food nexus in the coastal regions are very fragile under the severe influence of the fastest economic developing pace and the extensive anthropogenic activities in coastal zone. Therefore, comprehensive information on risk assessment and source apportionment of heavy metals as well as the seafood risk reduction using the coastal water-food-energy nexus analysis for sustainable development is necessary for food safety and sustainable development of the coastal regions. This study performed field sampling to investigate the occurrence, distribution, health risks, and possible sources of heavy metals in seafood. The risk reduction of seafood influenced by managing the coastal water-food-energy nexus for sustainable development was also evaluated. The final objective of this study is to obtain the comprehensive information on seafood safety in coastal regions at continental-scale to provide the basis for the food and environmental management.

\section{Materials and methods}

\section{Sample collection and pre-process}

Seafood samples including bivalves ( $n \geq 10$ for each sample), fish ( $n \geq 3$ for each sample), and crustaceans ( $n \geq 5$ for each sample) were randomly obtained from the local seafood market in 16 major coastal cities along the $18,000 \mathrm{~km}$ coastline of China in September of 2018 (Fig. 1). The bivalve samples included six species (Ruditapes philippinarum, Mactra veneriformis, Meretrix meretrix, Crassostrea virginica, Argopecten irradians, and Sinonovacula constricta) (Table S1). Fish samples included several species widely distributed along the coast of China or highly consumed (Pseudosciaena polyactis, Acanthogobius ommaturus, and Pampus argenteus). Moreover, the popularly indigenous fish species (Hexagrammos otakii and Cynoglossus semilaevis in the coastal region of northern China, Harpadon nehereus and Sillago japonica in the south and southeast of China) and several farmed fish species such as Pseudosciaena crocea, Psetta maxima, and Epinephelus fuscoguttatus were also collected. The crustacean samples referred to shrimps in this study, including Litopenaeus vannamei Boone, Marsupenaeus japonicas, and Parapenaeus hardwickii. All the seafood samples were washed with the local seawater, wrapped in polyethylene bags, and then sent to the laboratory through cold-chain transportation as soon as possible. The edible tissues of samples were dissected in the laboratory and the surface water was removed by kimwipes. Then, the tissues were dried by vacuum freeze dryer to reach constant weights. The tissue before and after freeze drying was carefully weighted.

\section{Sample analysis and quality control}

All the glassware vessels as well as polytetrafluoroethylene (PTFE) and polyethylene terephthalate (PET) tubes were cleaned by soaking in dilute $\mathrm{HNO}_{3}(1+3)$ for $24 \mathrm{~h}$ and rinsed with deionized water before use. Dried and homogenized tissue sample with $0.1 \mathrm{~g}$ was put into the PTFE digestion tube 

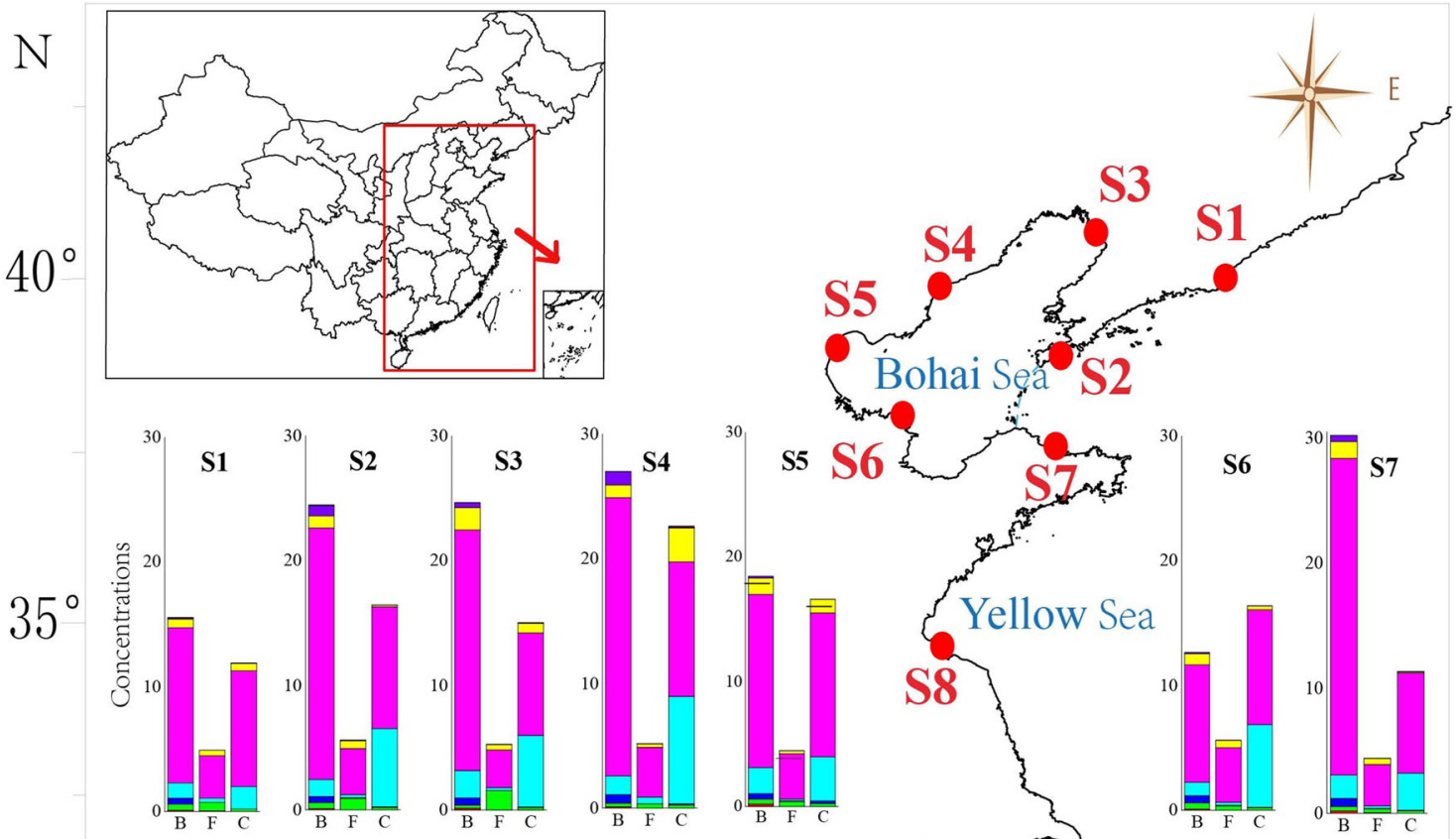

Bohai Sẹ S2

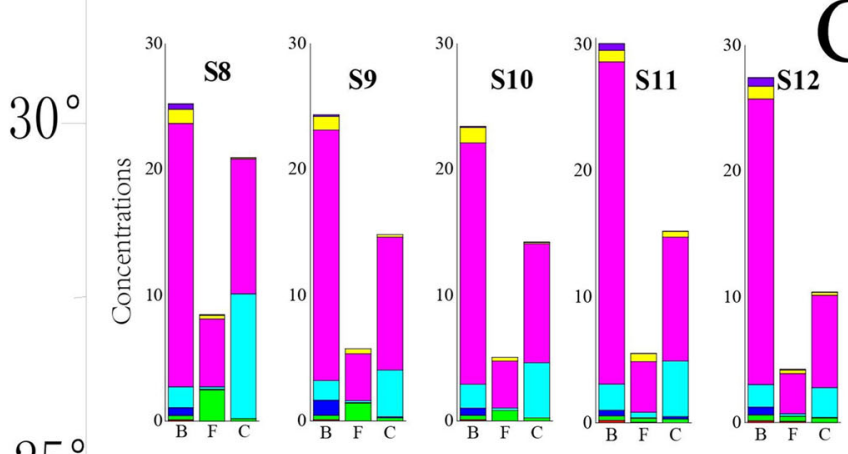

China

$25^{\circ}$

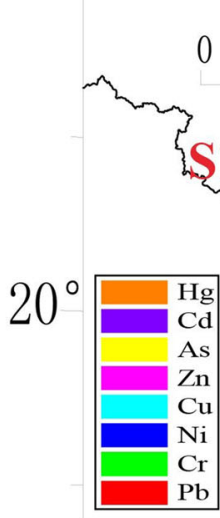

$200 \quad 400$
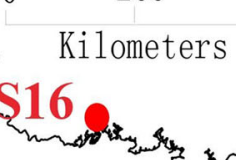

\section{0}
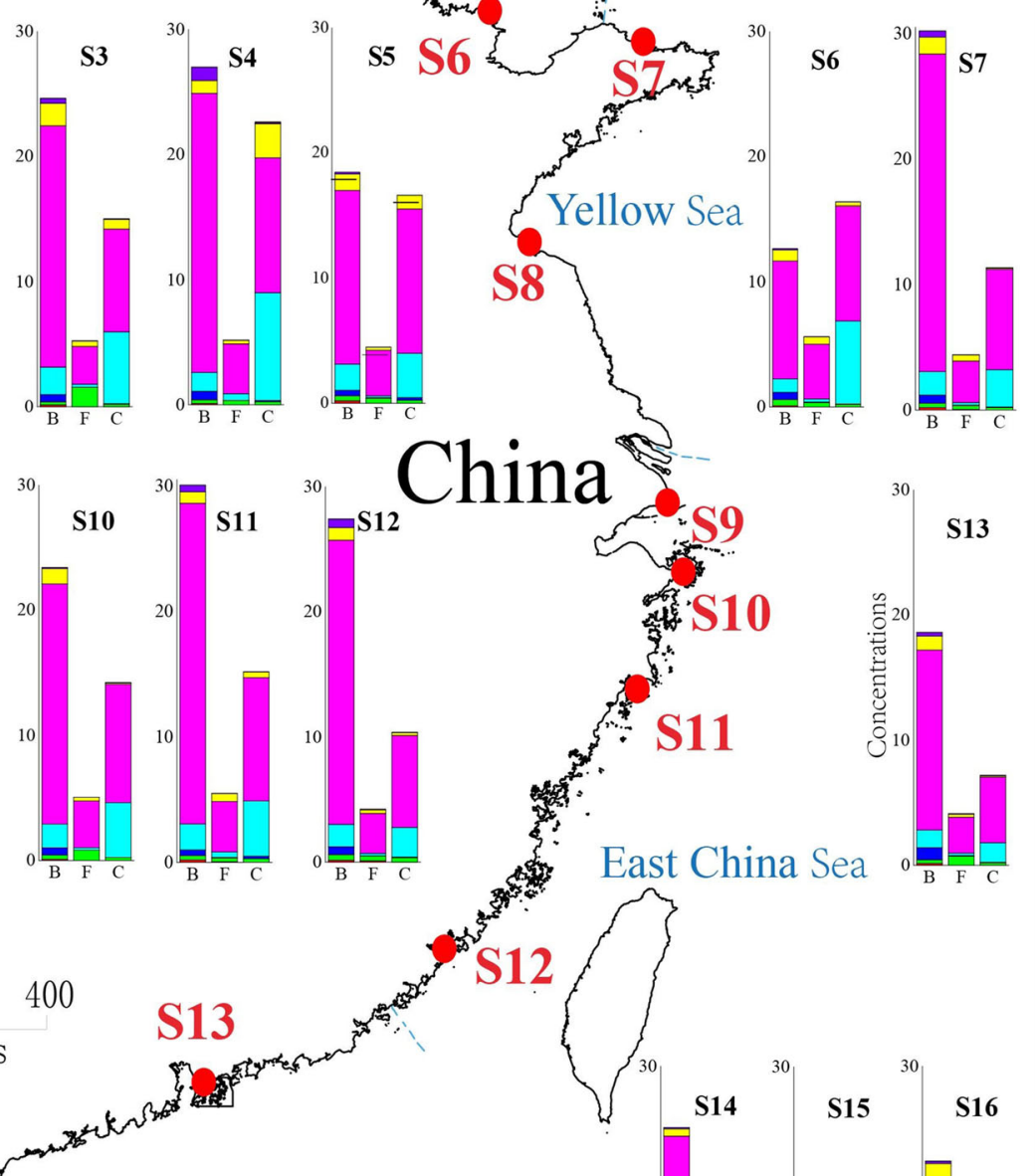

$105^{\circ}$

S15

South China Sea
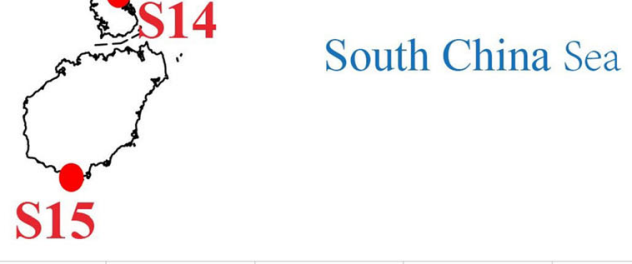

$$
110^{\circ}
$$

Fig. 1 Study area, sampling sites, and total concentrations of heavy metals ( $\mathrm{mg} / \mathrm{kg} \mathrm{ww})$ in the target seafood collected from the coastal areas in China. The $\mathrm{B}$ under the $x$-axis refers to bivalve molluscs while the $\mathrm{F}$ means fish. The $\mathrm{C}$ under the $x$-axis represents crustaceans

and $5 \mathrm{~mL}$ concentrated nitric acid were added. The sample was predigested at $85^{\circ} \mathrm{C}$ in water bath for $2 \mathrm{~h}$, and then put into the tightly sealed container with a ceramic protective outer layer. The container was placed into an oven and heated at $160{ }^{\circ} \mathrm{C}$ for $6 \mathrm{~h}$. After cooling down to the room temperature, the solution was diluted to the final volume of $50 \mathrm{~mL}$ with deionized water (Milli-Q Millipore $18.2 \mathrm{M} \Omega / \mathrm{cm}$ resistivity) and transferred into the PET tube. The samples were completely dissolved if the digested solution was clear without precipitation. 
The PerkinElmer ELAN DRC II inductively coupled plasma-mass spectrometer (ICP-MS) was used to determine the concentrations of $\mathrm{Cu}, \mathrm{Pb}, \mathrm{Zn}, \mathrm{Cd}, \mathrm{Cr}$, $\mathrm{As}$, and $\mathrm{Ni}$ in the coastal seafood samples. Hg was determined by atomic fluorescence spectrometer (Titian, AFS930, China). The response value of blank solution was subtracted to weaken the background interference. Each sample was analyzed in triplicate to minimize the analysis errors, and the result was shown as mean \pm standard deviation. Concentrations of heavy metals in the tissues were expressed as $\mathrm{mg} / \mathrm{kg}$ wet weight by converting dry weight to wet weight with the moisture content. Quality assurance was guaranteed by analyzing the concentrations of heavy metals in the standard mussel reference material (GBW 10024). The recoveries of all target heavy metals in the reference tissue samples were in the range of $85-115 \%$ to meet the analysis requirement of the method.

\section{Estimated daily intakes}

The estimated daily intakes (EDIs) could be used to determine the daily intake of the individual metal through oral exposure pathway (Griboff et al. 2017). The provisional tolerance weekly intake (PTWI) could be employed to estimate whether the negative effects of eating seafood routinely would occur or not (WHO 2004; Jafari et al. 2018). EDI was calculated by the following equation:

$\mathrm{EDI}=\frac{M C \times I R}{B W}$

where $M C$ refers to the metal concentration in tissue samples ( $\mu \mathrm{g} / \mathrm{g}$ wet weight), $I R$ means ingestion rate ( $\mathrm{g} /$ day), and $B W$ is the body weight $(\mathrm{kg})$. $I R$ was set as $55 \mathrm{~g}$ fish and $20 \mathrm{~g}$ bivalves per day for adult, $80 \mathrm{~g}$ fish and $5 \mathrm{~g}$ bivalves for children, and $10 \mathrm{~g}$ crustaceans for adults and children (Wang et al. 2005; Li et al., 2014; Zhao et al. 2016; FAO 2018). BW was set as $60 \mathrm{~kg}$ for adults and $30 \mathrm{~kg}$ for children.

\section{Health risk assessment}

Cancer risks $(C R)$ and hazard quotients $(H Q)$ were used to evaluate the health risk posed by heavy metals in bivalves and fish. Ingestion (eating seafood) was considered as the only exposure pathway of heavy metals in seafood. The health risks could be calculated by the following equations (USEPA 2004; Wen et al. 2019).

$$
\begin{aligned}
& C R(\text { individual })=\frac{M C_{i} \times I R \times E F_{i} \times E D_{i}}{B W \times A T} \times S F \\
& H Q(\text { individual })=\frac{M C_{i} \times I R \times E F_{i} \times E D_{i}}{B W \times A T \times R f D} \\
& \mathrm{tCR}=\sum C R(\text { individual })
\end{aligned}
$$

$\mathrm{t} H Q=\sum H Q($ individual $)$

where $M C$ refers to the metal concentration in tissue samples $(\mu \mathrm{g} / \mathrm{g}$ wet weight); IR means ingestion rate $(\mathrm{g} / \mathrm{d}) ; E F$ is the ingestion exposure frequency (days/year); $E D$ means ingestion exposure duration (year); $B W$ is the body weight $(\mathrm{kg})$; $A T$ refers to average lifespan (days); $S F$ is the cancer slope factor $(\mathrm{kg}$ day $/ \mathrm{mg})$; and $R f D$ is the oral reference dose $(\mathrm{mg} / \mathrm{kg}$ / day). The values of $S F$ and $R f D$ could be acquired from the Integrated Risk Information System and guideline of USEPA (USEPA 2016; IRIS 18). The other parameters in these equations referred to the previous study (Wu et al. 2016, 2020). Cancer risk is divided into five levels. Class I, II, III, IV, and V represent very low, low, moderate, high, and very high risk with the values of $\mathrm{CR} \leq 1 \times 10^{-6}, 1 \times 10^{-6}<\mathrm{CR} \leq 1 \times 10^{-4}, 1$ $\times 10^{-4}<\mathrm{CR} \leq 1 \times 10^{-3}, 1 \times 10^{-3}<\mathrm{CR} \leq 0.1, \mathrm{CR}>0.1$, respectively (Ullah et al. 2017; IRIS 2018). The risks of developing cancer over lifetime belonged to class I and II were acceptable for human.

\section{Source apportionment}

PMF model was used to determine the possible sources of target heavy metals in the seafood (USEPA 2014; Guan et al. 2019). As a factor analysis model, PMF has shown excellent ability in quantitatively determining contribution portions of different pollution sources (Guan et al. 2019; Wu et al. 2018). Two input datasets including pollution-data matrix and uncertainty-data matrix should be provided before performing PMF. The detailed information on PMF model referred to the guideline (USEPA 2014). Pb isotope was used to explore the possible $\mathrm{Pb}$ source for the target seafood. $\mathrm{Pb}$ isotopic ratios of target seafood (fish, clams, and oysters) with relatively high $\mathrm{Pb}$ content were determined by Phoenix thermal isotope mass spectrometry (TIMS) at Beijing Research Institute of Uranium Geology. Background ${ }^{208} \mathrm{~Pb} /{ }^{206} \mathrm{~Pb}$ in coal combustion ash, unleaded vehicle exhaust, and metallurgic dust was $2.1111,2.1240$, and 2.0768 while corresponding background ${ }^{207} \mathrm{~Pb} /{ }^{206} \mathrm{~Pb}$ was $0.8596,0.8715$, and 0.8529 , respectively (Tan et al. 2006). Background ${ }^{208} \mathrm{~Pb} /{ }^{206} \mathrm{~Pb}$ and ${ }^{207} \mathrm{~Pb} /{ }^{206} \mathrm{~Pb}$ in seawater were 2.0836 and 0.8516, respectively (Zurbrick et al. 2013). IsoSource was used to calculate the contribution of different $\mathrm{Pb}$ sources and the details of $\mathrm{Pb}$ source apportionment referred to the previous study (Phillips and Gregg 2003).

\section{Risk assessment under the scenario of fossil energy consumption control and clean coastal water action}

The risk of heavy metals in seafood under different scenario analysis was re-estimated based on the heavy metal concentration which was calculated following equation. 
$M_{i \text { metals after }}=M_{i \text { metals before }} \times P$

where the $M_{i}$ metals after and $M_{i}$ metals before refer to the concentration of a certain metals after and before the fossil fuel control or clean coastal water action. $P$ is the reduction percentage of the usage amounts of fossil fuel or target pollutants. The value of $P$ depends on the government policy. Energy policy with intensive consumption control has been implemented in China so that the fossil energy consumption would decrease by $15 \%$ in 2020 (scenario 1) and 50\% in 2050 (scenario 2) in comparison with that in 2015 (NDRC, National development and reform commission of China). Additionally, the target contaminants in seawater should be removed under the National Plan for Water Pollution Prevention and Control in Coastal Areas of China (scenario 3).

\section{Results and discussion}

\section{Distribution of heavy metals in seafood from coastal regions at continental scale}

Heavy metals in the target seafood showed significant spatial distribution (Fig. 1). Total contents of all target metals in bivalves ranged from 15.57 to $30.22 \mathrm{mg} / \mathrm{kg}$ ww (wet weight). Concentrations of all target heavy metals in seafood collected from S7 and S11 reached the highest owing to the high $\mathrm{Zn}$ content. Generally, bivalves in the Yellow Sea and East China Sea were polluted more seriously by heavy metals than the other area in China. Sum of concentrations of all target heavy metals in fish collected in coastal cities from northern to southern China were in the range of $4.13-8.45 \mathrm{mg} / \mathrm{kg}$ ww. The total contents of target heavy metals in crustaceans varied from 7.19 to 22.58 $\mathrm{mg} / \mathrm{kg}$ ww with crustaceans in S4 and S8 possessing the highest metal concentrations. Overall, seafood collected from S4, S8, $\mathrm{S} 11$, and S16 possessed higher total concentrations of target heavy metals while that collected from S13, S1, S6, and S15 showed relatively lower metal concentrations (Fig. 1). Interestingly, the top four and last four sites were equally distributed in the coastal areas of four seas in China. The minimal average concentration of heavy metals in seafood occurred in the Bohai Sea for $\mathrm{Pb}, \mathrm{Ni}$, and $\mathrm{Hg}$; in the Yellow Sea for As; and in the South China Sea for $\mathrm{Cr}, \mathrm{Cu}, \mathrm{Zn}$, and $\mathrm{Cd}$. The maximal average concentration of heavy metals in seafood occurred in the Bohai Sea for $\mathrm{Cu}, \mathrm{As}$, and Cd; in the Yellow Sea for Cr and Zn; and in the South China Sea for $\mathrm{Ni}, \mathrm{Pb}$, and $\mathrm{Hg}$. In most cases, the $\mathrm{Zn}$ and $\mathrm{Cu}$ were accumulated in the seafood with relatively high concentrations at continental scale. Obvious accumulation of As in the bivalve was also observed at continental scale. The territorial differentiation was observed in the heavy metal pollution of bivalves. The bivalves in the coast of Northern China tend to accumulate $\mathrm{Cd}$ while that in the coast of Southern China tend to accumulate Ni. The industrial structure difference between the Northern China and Southern China could lead to different patterns of fossil energy consumption and water pollution, which might subsequently cause the territorial differentiation in the heavy metal pollution of bivalves. Clear spatial variations were also found for $\mathrm{Cd}$ and $\mathrm{Ni}$ in the marine fish collect from Chinese waters (Zhang and Wang 2012).

Distribution of target heavy metals in edible tissues of various seafood was significantly different (Fig. 2). Zn existed with the highest average concentrations in the target seafood with the order of molluscs $>$ crustaceans $>$ fish. The highest $\mathrm{Zn}$ concentration in molluscs reached $418.8 \mathrm{mg} / \mathrm{kg} \mathrm{ww}$, approximately 36/ 70 times that in crustaceans/fish. Concentrations of $\mathrm{Cu}$ in molluscs showed significant variation with the range of 0.7-127.6 $\mathrm{mg} / \mathrm{kg}$ ww and the average of $6.3 \mathrm{mg} / \mathrm{kg} \mathrm{ww}$ while distribution of $\mathrm{Cu}$ in crustaceans/fish was relatively soothing with the average concentration of 4.6/0.3 mg/kg ww. $\mathrm{Zn}$ and $\mathrm{Cu}$ were essential elements for organism, and most of them were involved in the synthesis of enzyme (Storelli 2009), which might explain the relatively high concentrations of $\mathrm{Zn}$ and $\mathrm{Cu}$ in the target seafood. Concentrations of As in molluscs/fish/crustaceans were relatively high with the maximal value of 2.4/2.9/3.9 mg/ $\mathrm{kg}$ ww and concentrations of As in the fish and crustacean samples significantly varied. Concentrations of $\mathrm{Pb}, \mathrm{Ni}$, and $\mathrm{Cd}$ in fish and crustaceans were far less than those of bivalve molluscs. The highest concentration of $\mathrm{Pb}$ and $\mathrm{Cd}$ occurred in A. irradians while the highest $\mathrm{Ni}$ concentration occurred in three clams (M. meretrix, $M$. veneriformis, and $R$. philippinarum). Cr concentrations in fish were higher on the whole than those in molluscs and crustaceans. Concentrations of $\mathrm{Hg} / \mathrm{Cd} / \mathrm{Pb}$ were the lowest in molluscs/fish/ crustaceans with the highest value of $0.04 / 0.01 / 0.01 \mathrm{mg} / \mathrm{kg}$ ww. The concentrations of heavy metals followed the order of $\mathrm{Zn}>\mathrm{Cu}>\mathrm{As}>\mathrm{Ni}>\mathrm{Cr}>\mathrm{Cd}>\mathrm{Pb}>\mathrm{Hg}$ for molluscs, $\mathrm{Zn}>\mathrm{Cr}>$ $\mathrm{As}>\mathrm{Cu}>\mathrm{Ni}>\mathrm{Hg}>\mathrm{Pb}>\mathrm{Cd}$ for fish, and $\mathrm{Zn}>\mathrm{Cu}>\mathrm{As}>\mathrm{Cr}>$ $\mathrm{Ni}>\mathrm{Hg}>\mathrm{Cd}>\mathrm{Pb}$ for crustaceans. Similar to the previous study (Wang and Lu 2017), scallops (A. irradians) were polluted heavily among the bivalve molluscs with the major contributing factor of $\mathrm{Cd}$. The oyster samples in S14 and S16 were not safe enough to be eaten due to the exceptionally high $\mathrm{Cu}$ and $\mathrm{Zn}$ concentrations (around 10 times as much as other samples).

Safe thresholds for several metals in seafood have been recommended by the China Food and Drug Administration (CFDA 2017), European Community (EC 2006), World Health Organization (WHO 1982), Ministry of Agriculture and Rural Affairs of the People's Republic of China (MARA 2006), Food Standards Australia and New Zealand (FSANZ 2017), and Japan External Trade Organization (JETO 2011). Thresholds recommended by EC were more detailed and stricter than those of other countries and organizations so that EC thresholds were selected as the main criteria in this study. The concentrations of $\mathrm{Pb}$ and $\mathrm{Hg}$ in the edible tissues of all samples were below the limits set by $\mathrm{EC}$ while concentration of $\mathrm{Cr}$ in one wild-fish sample ( $P$. argenteus, collected from $\mathrm{S} 8$ ), As in two wild-fish samples 

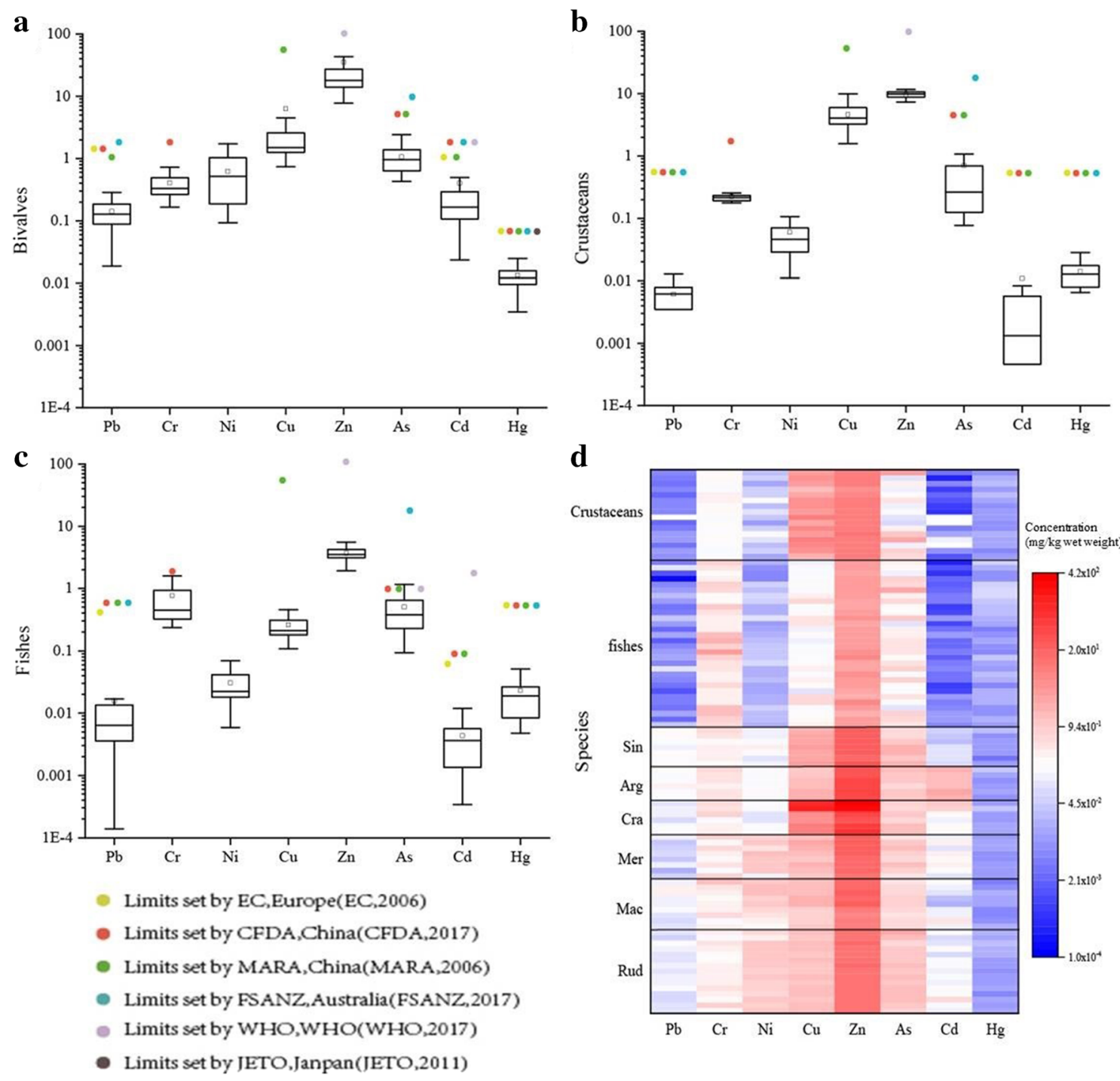

Fig. 2 The box plots of concentrations of heavy metals and threshold levels in bivalves (a), crustaceans (b), and fish (c) as well as the heat map of metal distributions in different species (d) including Ruditapes

philippinarum (Rud), Mactra veneriformis (Mac), Meretrix meretrix (Mer), Crassostrea virginica (Cra), Argopecten irradians (Arg), and Sinonovacula constricta $(\mathrm{Sin})$

(H. nehereus collected from S11 and S. japonica and S16), and $\mathrm{Cd}$ in all scallop samples (A. irradians) exceeded the limits (Fig. 2). Concentrations of $\mathrm{Cu}$ and $\mathrm{Zn}$ in two oyster samples (C. virginica, collected from $\mathrm{S} 14$ and S16) exceeded the limits set by China and WHO. The concentrations of Ni in target seafood of this study were consistent with those previously reported although there were no special limits for Ni (Liang et al. 2004; Copat et al. 2013). Interestingly, no heavy metals in the farmedfish exceeded the limits to suggest that it might be safer to consume farmed fish than wild fish.

\section{Daily intake of heavy metals by ingestion}

The EDI values of individual heavy metal in various seafood were calculated (Fig. 3a). The EDI values of target heavy

metals were much lower than provisional tolerance daily intake (PTDI) values (calculated based on PTWI, $\mathrm{Pb}, 3.6 ; \mathrm{Cr}$, $3.3 ; \mathrm{Ni}, 5 ; \mathrm{Cu}, 71.4 ; \mathrm{Zn}, 300 ; \mathrm{As}, 2.1 ; \mathrm{Cd}, 1.0 ; \mathrm{Hg}, 0.7 \mu \mathrm{g} / \mathrm{kg}$ bw/day), suggesting that the risks associated with the seafood consumption were relatively low. The average EDI values of target heavy metals in molluscs for adults were generally twice those for children while the average EDI values of target heavy metals in fish/crustaceans for children were approximately $3 / 2$ times those for adults.

The maximum edible amount of different seafood was estimated according to PTWI values (Table S2). Taking $\mathrm{Cd}$ as the limit factor, an adult could daily eat as more as $296 \mathrm{~g} R$. philippinarum, $342 \mathrm{~g}$ M. veneriformis, $290 \mathrm{~g} \mathrm{M}$. meretrix, or $30 \mathrm{~g}$ A. irradians while a child could only eat half of adult consumption quantity 
Fig. 3 EDI values (a1-2) and calculated daily intake amount (b1-4) with different seafood ratios of target heavy metals. Rud, Ruditapes philippinarum; Mac, Mactra veneriformis; Mer, Meretrix meretrix; Cra, Crassostrea virginica; Arg, Argopecten irradians; Sin, Sinonovacula constricta; W-F, wild fish; F-F, farmed fish; Cru, crustaceans
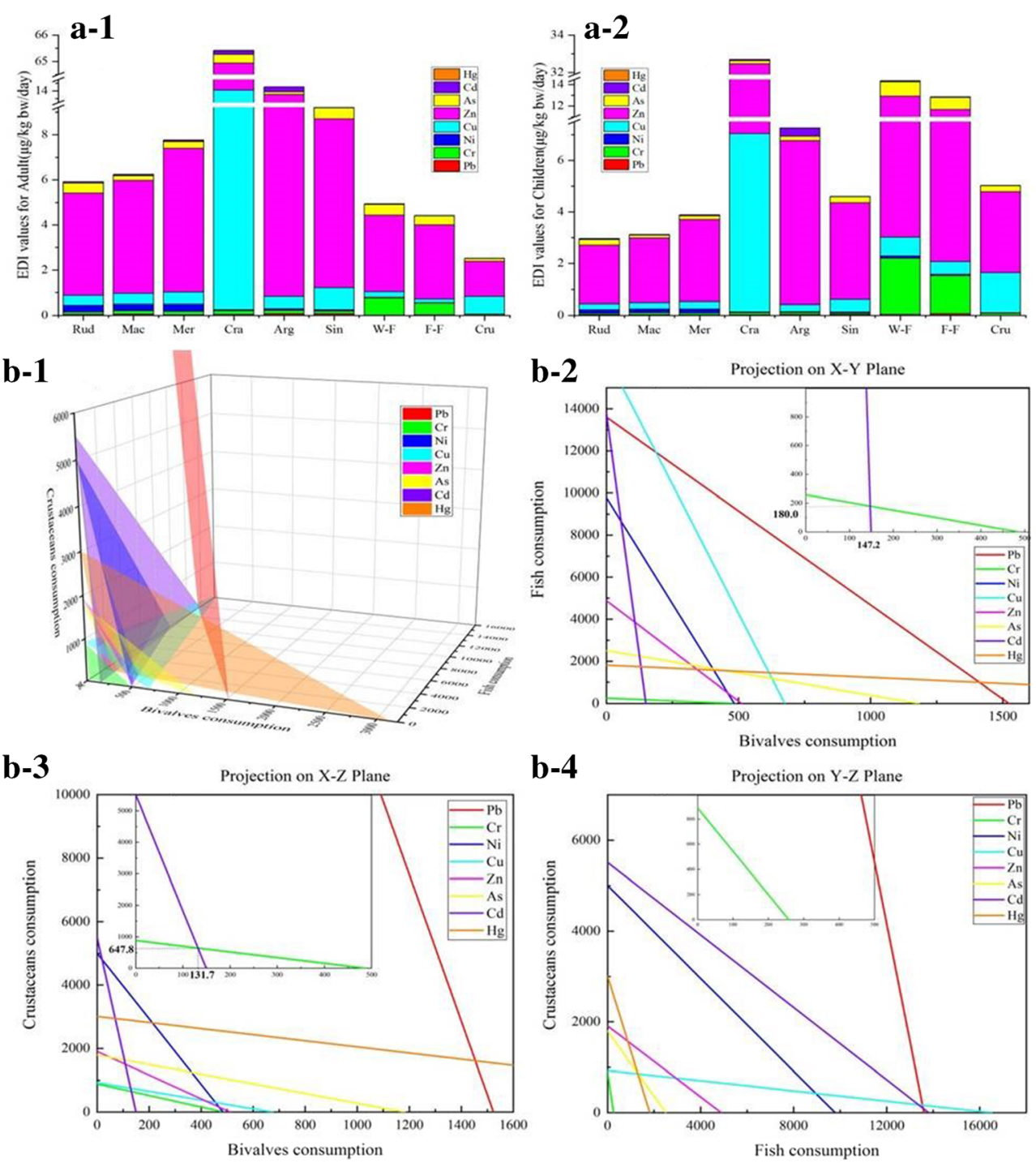

at the most. A daily consumption of $497 \mathrm{~g} \mathrm{~S}$. constricta, $233 \mathrm{~g}$ wild fish, or $328 \mathrm{~g}$ farmed fish could reach the PTWI limit for adult if taking $\mathrm{Cr}$ as limit factor, demonstrating that it might be safer to consume farmed fish than wild fish. In particular, an adult could only consume $99 \mathrm{~g} C$. virginica because of high $\mathrm{Cu}$ content in $C$. virginica. The daily intake of crustacean was higher than that of the remaining seafood, indicating that it might be safer to frequently eat crustaceans.

Different seafood consumption structure could obtain various PTWI values. The different consumption structures among bivalves, fish and crustaceans for an adult to reach the limit of eight elements of PTWI are shown in Fig. 3b-1. The concentrations of heavy metals in three kinds of seafood influenced the maximum daily intake amount together. An upper limit could always be reached no matter how much seafood an adult consumed, which suggested that an adult must reduce the consumption of fish or crustaceans if he ate more bivalves. According to this criterion, only 149/258/888 g bivalves/fish/crustaceans could be eaten individually and $142 \mathrm{~g}$ of them could be taken in equally (Table S3). Bivalves often contributed to a greater proportion of heavy metals than fish or crustaceans. To make the consumption scenarios simpler, the projection on three planes (X-Y, X-Z, $\mathrm{Y}-\mathrm{Z}$ ) in coordinate were made to show three typical situations. In the first case with the bivalves and fish appearing on table at the same time (Fig. 3b-2), Cr was the limit factor when the bivalves consumption was less than $147.2 \mathrm{~g}$ because of the high $\mathrm{Cr}$ content in fish while $\mathrm{Cd}$ was the limit factor due to the high $\mathrm{Cd}$ content in bivalves when the bivalves consumption exceeded $147.2 \mathrm{~g}$. The maximum seafood ingestion amount under safety was $327.2 \mathrm{~g}$ (147.2 $\mathrm{g}$ bivalves $+180 \mathrm{~g}$ fish) for the first case. The $\mathrm{Cr}$ was the limit factor if less than $131.7 \mathrm{~g}$ bivalves were eaten while $\mathrm{Cd}$ served as the limit factor if bivalve consumption exceeded $131.7 \mathrm{~g}$ for the second case with bivalves and crustaceans being consumed (Fig. 3b-3). An adult could eat as more as $887.6 \mathrm{~g}(0 \mathrm{~g}$ bivalves + 
$887.6 \mathrm{~g}$ crustaceans) for this case, indicating the metals in crustaceans were much less than those in bivalves. $\mathrm{Cr}$ was the only limit factor to obtain the maximum ingestion of $887.6 \mathrm{~g}$ ( $0 \mathrm{~g}$ fish $+887.6 \mathrm{~g}$ crustaceans $)$ in the last case with fish and crustaceans being simultaneously consumed (Fig. 3b4), illustrating that the crustaceans were the safest among the target seafood.

Specifically speaking, the bivalve consumption was restricted to the $\mathrm{Cd}$ content because the average concentration of $\mathrm{Cd}$ in bivalves $(0.4021 \mu \mathrm{g} / \mathrm{g} \mathrm{ww})$ was extremely higher than that of fish $(0.0043 \mu \mathrm{g} / \mathrm{g} \mathrm{ww})$ and crustaceans $(0.0108$ $\mu \mathrm{g} / \mathrm{g} \mathrm{ww}$ ) while the fish and crustacean consumption was limited by the $\mathrm{Cr}$ content. Bivalves often accounted for a greater proportion in metal ingestion contribution while the crustaceans contributed less. Therefore, consuming more fish or crustaceans (especially the crustaceans) and less bivalves could reduce the health risk.

\section{Health risks posed by heavy metals in target seafood}

Hazard quotients $(H Q)$ were used to evaluate the non-cancer health risk of heavy metals through seafood ingestion for both adults and children (Fig. $4 \mathrm{a}$ and b). Most of $H Q$ values ( $99.1 \%$ for adult and $97.7 \%$ for children) of individual metals in edible tissues of different seafood were less than 1.0,
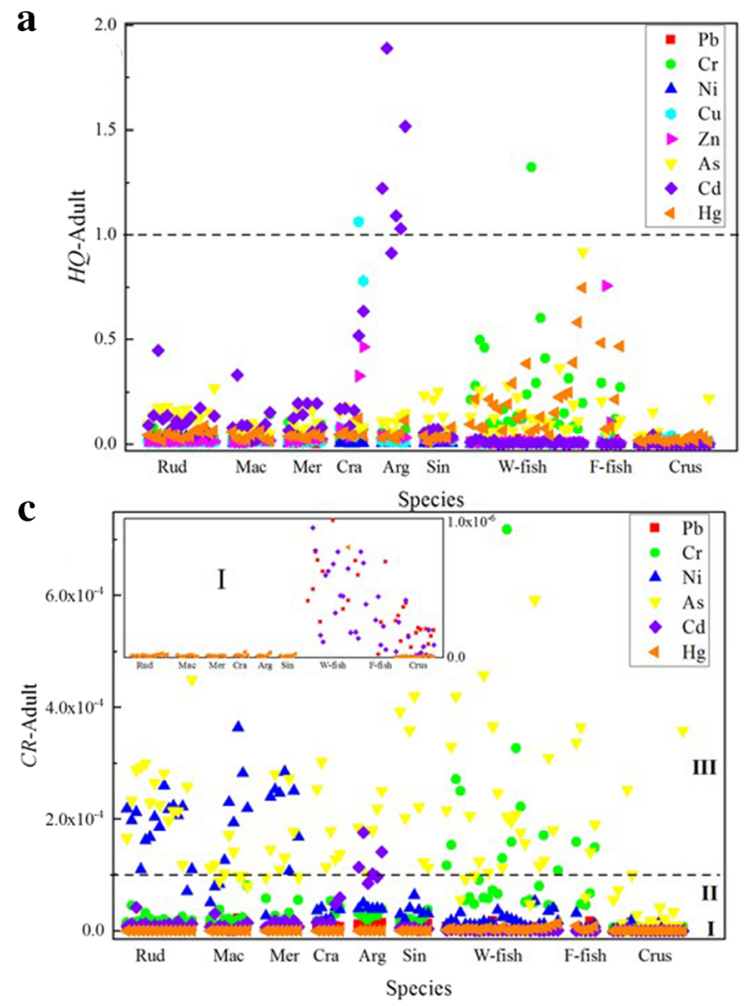

Fig. 4 The hazard quotient $(H Q)$ and cancer risk $(C R)$ of heavy metals in edible tissues of seafood samples. When $C R \leq 1 \times 10^{-6}, 1 \times 10^{-6}<C R \leq 1$ $\times 10^{-4}, 1 \times 10^{-4}<C R \leq 1 \times 10^{-3}, 1 \times 10^{-3}<C R \leq 0.1$ or $C R>0.1$, it means cancer risk belongs to level I, II, III, IV, or V, respectively. Rud, indicating that most of seafood was safe enough to be eaten. However, $H Q$ values of $\mathrm{Cu}$ in $C$. virginica sample (collected in S14), Cd in 5 A. irradians samples (collected from S2, S4, $\mathrm{S} 8, \mathrm{~S} 11$, and S12) and $\mathrm{Cr}$ in one wild-fish (P. argenteus, collected from S8) exceeded the safe threshold of 1.0, suggesting that heavy metals in these kinds of seafood would pose high health risks for both adults and children. The $H Q$ values of $\mathrm{Cr}$ in four fish samples, As in two wild-fish, and $\mathrm{Cd}$ in six fish samples were only greater than 1.0 for children, suggesting that children were more susceptible to the harmful effects of heavy metals in seafood. According to previous investigation on local seafood of Xiamen and Shenzhen city, both As and Cd also pose relatively high potential risks (Zhao et al. 2016; Zhu et al. 2017). The total hazard quotient ( $t H Q$ ) was the sum of the $H Q$ of individual metals. The $t H Q$ values (Fig. 5) of all A. irradians and two $C$. virginica samples for adults and children exceeded 1.0 and $t H Q$ values of $83 \%$ of fish for children were greater than 1.0. $\mathrm{Cu}$ in $C$. virginica and $\mathrm{Cd}$ in A. irradians were major risk contributors while $\mathrm{Cr}$ and $\mathrm{Hg}$ were the primary contributors of potential non-cancer risk passed by eating fish, especially for children. In addition, As was another important risk contributor in both bivalves and fish. Crustacean was the safest seafood for both adult and children according to the $t H Q$ values. The farmed fish posed relatively low risk in comparison with the wild fish, indicating

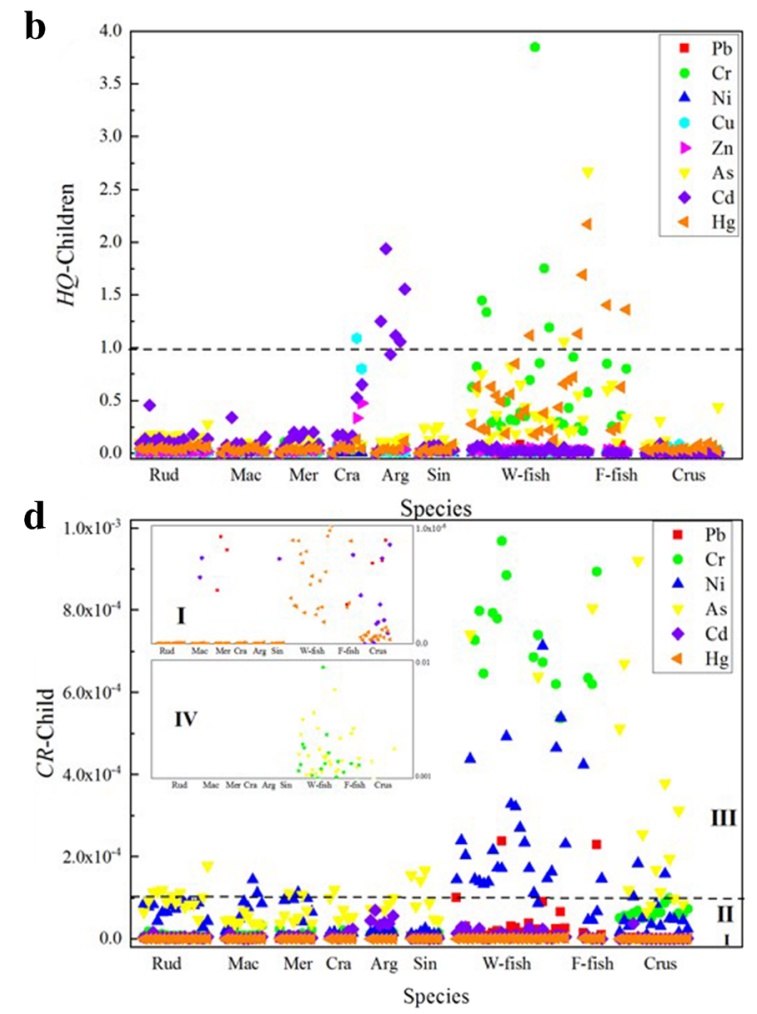

Ruditapes philippinarum; Mac, Mactra veneriformis; Mer, Meretrix meretrix; Cra, Crassostrea virginica; Arg, Argopecten irradians; Sin, Sinonovacula constricta, W-fish, wild fish; F-fish, farmed fish; Crus, crustaceans 


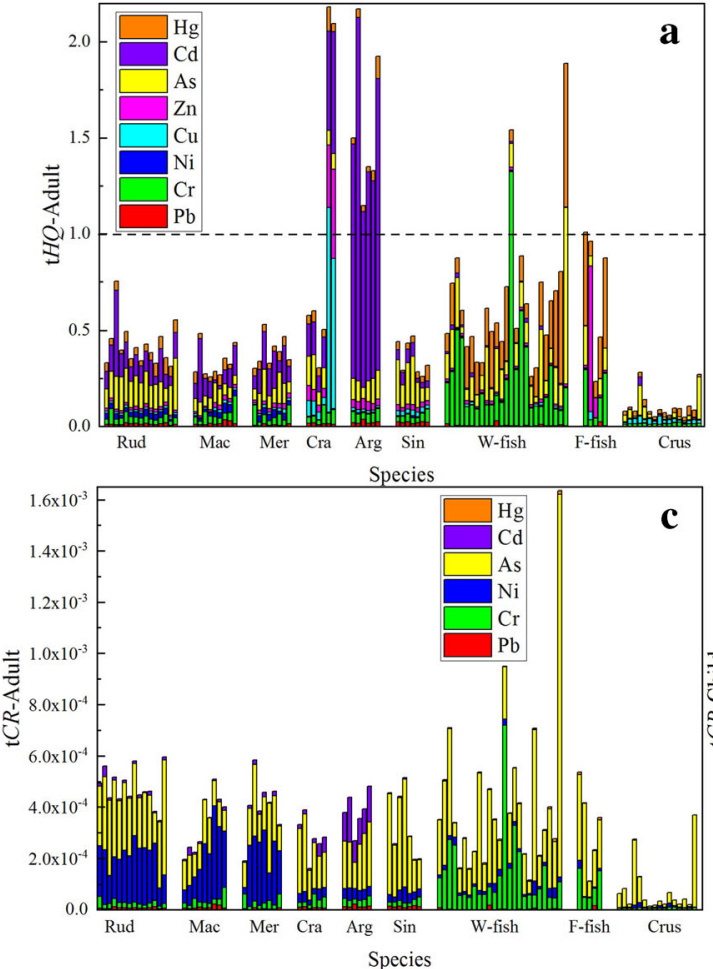

Fig. 5 The total hazard quotient $(\mathrm{t} H Q)$ and total cancer risk ( $\mathrm{t} C R$ ) value of six heavy metals in edible tissues of collected samples. Rud, Ruditapes philippinarum; Mac, Mactra veneriformis; Mer, Meretrix meretrix; Cra,

that it might be safer to consume farmed fish than wild fish while industrial mariculture should be an essential approach for the seafood safety in coastal zone. The green development policy in the industrial aquaculture has been implemented in China in 2020 (MARA (Ministry of Agriculture and Rural Affairs of the People's Republic of China), 2006).

It is necessary to point out that the $t H Q$ value is a highly conservative and relative index to possibly ignore the adverse health effects actually ongoing (Wang et al. 2005). Cancer risk (CR) index represented the increasing probability of developing cancer over lifetime because of exposure to contaminant. $C R$ values of $\mathrm{Cu}$ and $\mathrm{Zn}$ were not calculated since these metals were generally regarded non-carcinogenic (IRIS 2018). The $C R$ values of the remaining metals in different seafood were calculated (Fig. $4 \mathrm{c}$ and d). The $C R$ values of target metals in most of seafood samples $(75.9 \%$ for adult and $78.4 \%$ for children) were below $10^{-4}$ (class I and II) while heavy metals in $7.5 \%$ of samples could lead to high cancer risk (class IV) only for children. Three metals including As, Ni, and $\mathrm{Cr}$ performed as the major carcinogens. As in bivalves and fish for adult and crustaceans for children could cause moderate risks (class III) while As in fish could cause high cancer risks for children (class IV). As in crustaceans for adult and in bivalves for children would lead to the low risks (class II). Ni in bivalves (for adult) and fish (for children) caused moderate risks (class III) while $\mathrm{Cr}$ in many fish samples

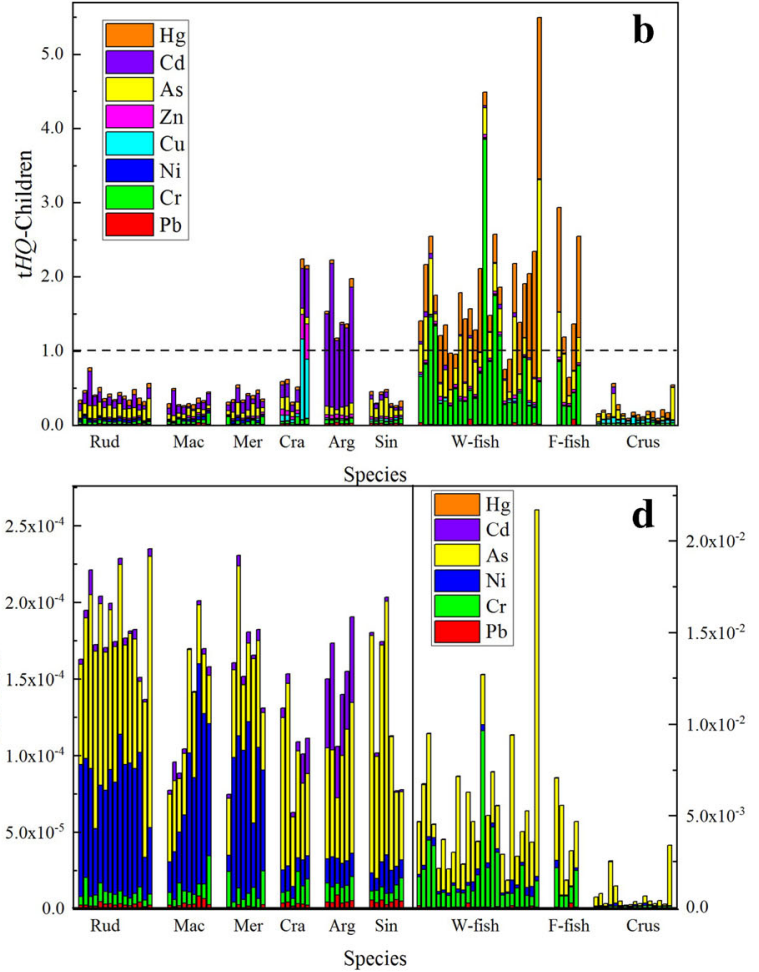

Crassostrea virginica; Arg, Argopecten irradians; Sin, Sinonovacula constricta; W-fish, wild fish; F-fish, farmed fish; Crus, crustaceans

caused moderate risks (class III) for adult and high cancer risks for children (class IV). The remaining heavy metals in seafood samples posed low risks for both adults and children.

The $t C R$ values (Fig. 5) of the bivalve ingestion for adults ranged from $1.60 \times 10^{-4}$ to $5.96 \times 10^{-4}$ with a mean value of $3.87 \times 10^{-4}$, higher than those for children ranging from $6.29 \times$ $10^{-5}$ to $2.35 \times 10^{-4}$ with a mean value $1.53 \times 10^{-4}$. The cancer risks posed by fish consumption were in the range of $1.12 \times$ $10^{-4}-1.64 \times 10^{-3}$ with mean value of $4.13 \times 10^{-4}$ for adults while those ranged from $1.48 \times 10^{-3}$ to $2.17 \times 10^{-2}$ with a mean value of $5.47 \times 10^{-3}$ for children. The tCR values of crustacean consumption ranged from $1.51 \times 10^{-5}$ to $3.69 \times 10^{-4}$ (mean value $7.88 \times 10^{-5}$ ) for adults while those for children ranged $1.69 \times 10^{-5}$ to $3.40 \times 10^{-3}$ (mean value $7.25 \times 10^{-4}$ ). The cancer risks of heavy metals in seafood for adults through ingestion followed the order of fish (moderate risk) $>$ bivalves (moderate risk) $>$ crustaceans (low risk) and fish (high risk) $>$ crustaceans (moderate risk) $>$ bivalves (moderate risk) for children. As was the biggest contributor with the $51 \%$ proportion among the heavy metals in bivalves and $\mathrm{Ni}$ was the second contributor with $34 \%$ of contribution. As and $\mathrm{Cr}$ in fish were the main risk contributors with $62 \%$ and $32 \%$ proportion while As in crustaceans was the major cancer risk contributor with $85 \%$ proportion. In a word, the biggest factor of cancer risk was metal As remnant in all target seafood, which was in accordance with early report (IRIS 2018). It was worth mentioning 
that $\mathrm{Pb}$ and $\mathrm{Hg}$ in these three kinds of seafood contributed little cancer risks $(<2 \%)$ for both adults and children.

\section{Source apportionment of heavy metals in target seafood}

Distribution of heavy metals in various marine organisms might be affected by different habitats of these organisms (Cheggour et al. 2005). Additionally, anthropogenic activities have significantly influenced the distribution and accumulation of heavy metals in marine organisms. Therefore, it is necessary and important to identify the possible sources of heavy metals in target seafood for better food safety and environmental management. The correlation analysis was used to primarily determine the possible relationship between the target heavy metals (Fig. S1). Different metals varying with species was closely related to the difference in biokinetics and bioaccumulation strategies (Wang and Lu 2017). Three metals $(\mathrm{Cu}, \mathrm{Zn}$, and $\mathrm{Hg})$ in bivalves were strongly correlated with each other $(p<0.05$ or $p<0.01)$, and strong correlation existed between $\mathrm{Ni}$ and $\mathrm{Pb}$. As- $\mathrm{Hg}$ and $\mathrm{Cu}-\mathrm{Cd}$ were in correlation for fish while $\mathrm{Pb}-\mathrm{As}$, $\mathrm{As}-\mathrm{Cd}, \mathrm{Pb}-\mathrm{Cd}, \mathrm{Cu}-\mathrm{Zn}$, and $\mathrm{Cu}-\mathrm{Cd}$ presented a significant correlation for crustaceans. It was interesting that $\mathrm{Pb}, \mathrm{Ni}, \mathrm{Cu}, \mathrm{Zn}, \mathrm{As}, \mathrm{Cd}$, and $\mathrm{Hg}$ could always be found to correlate with other metals, implying their similar biological characteristics. However, $\mathrm{Cr}$ did not correlate with any other metal $(p>0.05)$, suggesting its special characteristic.

The PMF model was used to identify the possible sources and source proportions of heavy metals in fish, bivalve molluscs (oysters and clams), and crustaceans collected from different coastal cities of China (Fig. 6a-d). Four possible sources including seawater (natural source), coal combustion ash (anthropogenic source), vehicle exhaust (anthropogenic source), and metallurgic dust (anthropogenic source) were determined as the main sources of heavy metals in target seafood. Among these pollution sources, fossil energy consumption (coal combustion and vehicle exhaust) were essential sources for the heavy metal pollution in seafood. Different heavy metals in different seafood possessed different major source (Fig. 6a-d). Taking Hg as an example, seawater was the main source for $\mathrm{Hg}$ in fish/oyster with contribution proportion of $56.6 \% / 63.7 \%$ while vehicle exhaust/metallurgic dust was the main source for $\mathrm{Hg}$ in crustacean/clam with contribution proportion of $61.8 \% / 40.5 \%$. In contrast, coal combustion ash/seawater/vehicle exhaust/metallurgic dust was the major source for $\mathrm{Cr}$ in fish/oyster/clam/crustacean with contribution proportion of $81.0 \% / 33.4 \% / 34.9 \% / 48.3 \%$. Different seafood was significantly influenced by different sources. Heavy metals (except As and $\mathrm{Hg}$ ) in fish were mainly affected by anthropogenic sources while heavy metals excluding $\mathrm{Cd}$ and $\mathrm{Cr}$ in oysters were significantly influenced by natural source (seawater). Moreover, heavy metals in clam (except
$\mathrm{Cd}$ ) and in crustacean (except $\mathrm{Pb}$ and $\mathrm{Ni}$ ) were also mainly affected by different anthropogenic sources.

Lead isotopes are useful indices for identifying the possible sources of $\mathrm{Pb}$ in different matrices (Komárek et al., 2008; Fillion et al. 2014). Using lead isotope ratio method, the $\mathrm{Pb}$ in seafood was proved to be mainly enriched from various anthropogenic pollution sources (Ip et al. 2005; Tong et al. 2016). Therefore, this study used $\mathrm{Pb}$ isotopic ratios to determine the $\mathrm{Pb}$ sources and their proportions (Fig. 6e-f). Total 13 seafood samples mainly including fish and molluscs with relatively high $\mathrm{Pb}$ concentration were further tested for $\mathrm{Pb}$ isotopic ratios. Ratios of ${ }^{208} \mathrm{~Pb} /{ }^{206} \mathrm{~Pb}$ in different seafood samples ranged from 2.0886 to 2.1226 while those of ${ }^{207} \mathrm{~Pb} /{ }^{206} \mathrm{~Pb}$ were in the range of $0.8441-0.8680$. Oysters possessed lower ratios of ${ }^{208} \mathrm{~Pb} /{ }^{206} \mathrm{~Pb}$ and ${ }^{207} \mathrm{~Pb} /{ }^{206} \mathrm{~Pb}$ while fish showed higher $\mathrm{Pb}$ isotopic ratios (Fig. 6e). Source apportionment results based on $\mathrm{Pb}$ isotopic ratios showed that local seawater/coal combustion ash/vehicle exhaust served as the main $\mathrm{Pb}$ source for oyster/clam/fish, which was similar to the PMF results (Fig. $6 \mathrm{f})$.

\section{Risk reduction of target seafood under the scenario of fossil energy consumption control and clean coastal water action}

The decreased consumption of fossil energy or clean seawater action might reduce the health risk of heavy metals in seafood since fossil energy consumption (coal combustion and vehicle exhaust) and seawater were proved to be the main source of heavy metals in seafood. Therefore, the $t H Q$ and $t C R$ values changed under three scenarios (Fig. 7). The fossil energy consumption in China would decrease by $15 \%$ in 2020 (scenario 1) and $50 \%$ in 2050 (scenario 2) in comparison with that in 2015 (NDRC, National development and reform commission of China). The decline of health risks could be obviously observed under the fossil energy control (scenarios 1 and 2). Moreover, the $t H Q$ values in seafood such as the silver pomfret collected in S8 and the turbot in S7 were less than the threshold of 1.0 after energy control. Both $t H Q$ and $t C R$ values of seafood decreased by $7 \%$ (3-10\% for $\mathrm{t} H Q$ and 5-7\% for tCR in different categories) when energy consumption decreased by $15 \%$ while both $\mathrm{t} H Q$ and $\mathrm{t} C R$ values decreased by $23 \%$ (9-34\% for $\mathrm{t} H Q$ and $17-25 \%$ for $\mathrm{tCR}$ in different categories) when fossil energy consumption decreased by $50 \%$. Approximately $10 \% / 34 \%$ of $t H Q$ value was reduced under scenario $1 / 2$ for crustaceans serving as the biggest beneficiary of energy consumption reduction, mainly because the percentage of energy-source metals (such as $\mathrm{Cu}, \mathrm{Hg}$, and $\mathrm{Zn}$ ) in crustaceans was bigger than that of other seafood. Several heavy metals including $\mathrm{Cr}, \mathrm{Cu}$, As, and $\mathrm{Hg}$ contribute to $66.8 \%, 38.7 \%, 37.4 \%$, and $34.0 \%$ of decrease in non-cancer health risk for fish, oyster, clam, and crustacean, respectively. Meanwhile, $\mathrm{Cr}$ in fish and As in clam/oyster/fish/crustacean 

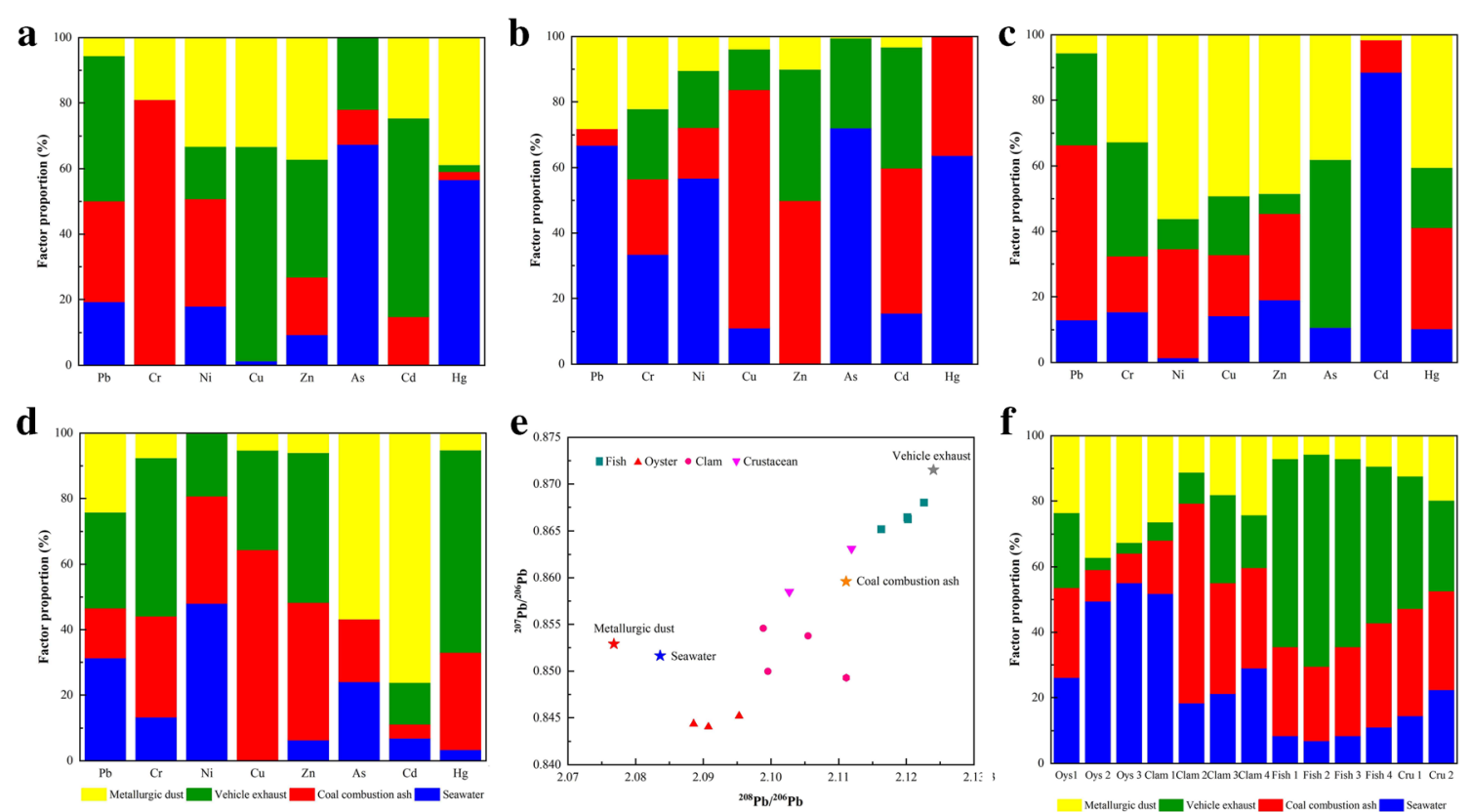

Fig. 6 The PMF source proportion for fish (a), oyster (b), clam (c), and crustacean (d), as well as the $\mathrm{Pb}$ isotopic ratios (e) and $\mathrm{Pb}$ source apportionment (f). The Oys and Cru refer to oyster and crustacean, respectively

were the biggest promoter for cancer risk decline, with risk reduction contribution of over $40 \%$.

Meanwhile, it would be helpful to remove the contaminants in seawater under the National Plan for Water
Pollution Prevention and Control in Coastal Areas of China (scenario 3). Under the clean coastal water action (scenario 3), the $\mathrm{t} H Q$ values decreased by $34 \%$ (in the range of $10-74 \%$ ) while $\mathrm{t} C R$ values were reduced by $25 \%$ (in the range of 9
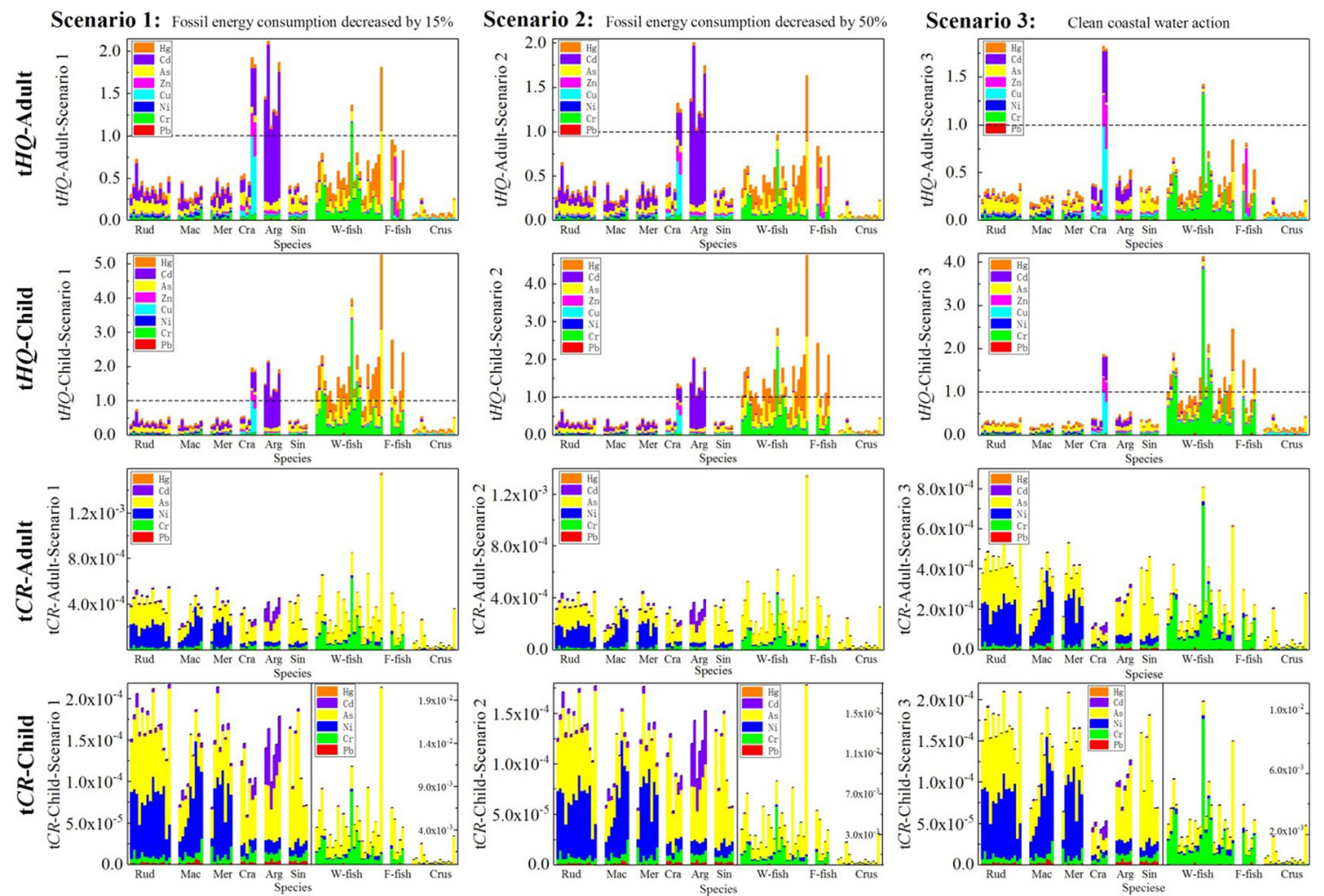

Fig. 7 The total hazard quotient $(\mathrm{t} H Q)$ and total cancer risk ( $\mathrm{t} C R)$ value of heavy metals in edible tissues under different energy consumption and water protection policy scenarios. Rud, Ruditapes philippinarum; Mac,
Mactra veneriformis; Mer, Meretrix meretrix; Cra, Crassostrea virginica; Arg, Argopecten irradians; Sin, Sinonovacula constricta; W-fish, wild fish; F-fish, farmed fish; Crus, crustaceans 
$60 \%$ ). A sharp decline appeared for scallop after the clean coastal water action and all $t H Q$ values of scallop were below 1.0 threshold because seawater-sourced Cd was removed. A noteworthy decline (about $60 \%$ ) occurred in the $t C R$ of oyster owing to the decreased concentration of As. Clean coastal water action would reduce the concentrations of $\mathrm{Cd}$ in clam, As in oyster and crustacean, and $\mathrm{Hg}$ and As in fish to further reduce the non-cancer health risk by $88 \%, 34.9 \%, 72.6 \%$, $53.6 \%$, and $44.2 \%$, respectively. As served as the biggest contributor for cancer risk reduction, contributing to $42.6 \%$ / $77.7 \% / 96.7 \% / 79.5 \%$ of total cancer risk decrease in clam/oyster/fish/crustacean. The $\mathrm{t} H Q$ values for both adults and children could drop below 1.0 if simultaneously controlling fossil energy consumption and performing clean coastal water action. Therefore, both the fossil-energy-controlling policy and clean coastal water action were beneficial to the seafood safety in terms of reducing the target heavy metals in marine organism.

\section{Conclusions}

This study conducted comprehensive investigations on risk assessment and source apportionment of heavy metal pollution as well as the coastal water-food-energy nexus for sustainable development in terms of seafood and coastal pollution. Concentrations of heavy metals in seafood varied with sampling regions and species with the total concentration order of bivalve molluscs $>$ crustaceans $>$ fish. The limits of seafood ingestions largely depended on the contents of $\mathrm{Cr}$ and $\mathrm{Cd}$ in edible tissues. Seafood collected from coastal regions was generally safe enough based on normal intake assessment. The scallop and oyster were the species exerting the largest health threat to people while children might face more health risks posed by heavy metals in fish because of the relatively large fish ingestion. Heavy metals including As, $\mathrm{Cd}$, and $\mathrm{Ni}$ were the main cancer risk contributors of seafood consumption. Possible main sources including seawater, fossil energy consumption (coal combustion and vehicle exhaust), and metallurgic dust could affect heavy metals in the target seafood. According to the policy scenario analysis, the fossilenergy-controlling policy and clean coastal water action were beneficial to the seafood safety by reducing target heavy metals in marine organisms. The farmed fish posed relatively low risk in comparison with the wild fish demonstrating that the green development in industrial mariculture was another essential approach for the seafood safety in coastal zone. This study provided initial information on seafood safety and the water-food-energy nexus sustainability in coastal regions in terms of heavy metal pollution.

Supplementary Information The online version contains supplementary material available at https://doi.org/10.1007/s11356-020-11904-8.
Availability of data and materials The datasets used and/or analyzed during the current study are available from the corresponding author on reasonable request.

Author contributions Jian Lu: conceptualization; data curation; investigation; methodology; project administration; writing — original draft and review. Yichen Lin: formal analysis; investigation; methodology; writing - original draft. Jun Wu: methodology; investigation; software; writing — review and editing. Cui Zhang: methodology; investigation.

Funding This work was supported by the National Natural Science Foundation of China (41671319), Taishan Scholars Program of Shandong Province (No. tsqn201812116), Science and Technology Service Network Initiative of the Chinese Academy of Sciences (KFJSTS-QYZX-114), One Hundred-Talent Plan of Chinese Academy of Sciences (Grant numbers of Y629041021), Two-Hundred Talents Plan of Yantai (No. Y739011021), and Youth Innovation Team Project for Talent Introduction and Cultivation in Universities of Shandong Province.

\section{Compliance with ethical standards}

Competing interests The authors declare that they have no competing interests.

Ethics approval and consent to participate Not applicable.

Consent for publication All the authors approved the final manuscript and agreed to its publication in the Environmental Science and Pollution Research.

\section{References}

Al-Saidi M, Elagib NA (2017) Towards understanding the integrative approach of the water, energy and food nexus. Sci Total Environ 574:1131-1139

Backer LC, Bolton B, Litz JA, Trevillian J, Kieszak S, Kucklick J (2019) Environmental contaminants in coastal populations: Comparisons with the National Health and Nutrition Examination Survey (NHANES) and resident dolphins. Sci Total Environ 696:134041

Bertocci I, Dell'Anno A, Musco L, Gambi C, Saggiomo V, Cannavacciuolo M, Lo Martire M, Passarelli A, Zazo G, Danovaro R (2019) Multiple human pressures in coastal habitats: variation of meiofaunal assemblages associated with sewage discharge in a post-industrial area. Sci Total Environ 655:1218-1231

BFMA (Bureau of Fisheries of the Ministry of Agriculture) (2019) China Fishery Statistical Yearbook http://www.jiubanmoagoven/sjzz/ yzjzw.

Bosch AC, O'Neill B, Sigge GO, Kerwath SE, Hoffman LC (2016) Heavy metals in marine fish meat and consumer health: a review. J Sci Food Agric 96:32-48

CFDA (China Food and Drug Administration) (2017) National Food Safety Standard-Limits for contaminants in food (GB 2762-2017).

Cheggour M, Chafik A, Fisher NS, Benbrahim S (2005) Metal concentrations in sediments and clams in four Moroccan estuaries. Mar Environ Res 59:119-137

Chen YM, Li HC, Tsao TM, Wang LC, Chang Y (2014) Some selected heavy metal concentrations in water, sediment, and oysters in the ErRen estuary, Taiwan: chemical fractions and the implications for biomonitoring. Environ Monit Assess 186:7023-7033

Copat C, Arena G, Fiore M, Ledda C, Fallico R, Sciacca S, Ferrante M (2013) Heavy metals concentrations in fish and shellfish from 
eastern Mediterranean Sea: Consumption advisories. Food ChemToxicol 53:33-37

EC (European Commission) (2006) Commission Regulation No. 1881/ 2006 of 19 December 2006 setting maximum levels of certain contaminants in foodstuff. Off J Eur Union: Legis Ser 65:5-24

Fakhri Y, Saha N, Miri A, Baghaei M, Roomiani L, Ghaderpoori M, Taghavi M, Keramati H, Bahmani Z, Moradi B, Bay A, Pouya RH (2018) Metal concentrations in fillet and gill of parrotfish (Scarus ghobban) from the Persian Gulf and implications for human health. Food ChemToxicol 118:348-354

FAO (Food and Agriculture Organization of the United Nations) (2018) FAO year book-Fishery and Aquaculture Statistics, p 2016. http:// www.faoorg/statistics/en

Fillion M, Blais JM, Yumvihoze E, Nakajima M, Workman P, Osborne G, Chan HM (2014) Identification of environmental sources of lead exposure in Nunavut (Canada) using stable isotope analyses. Environ Int 71:63-73

FSANZ (Food Standards Australia and New Zealand) (2017) Australia New Zealand Food Standards Code, Standard 1.4.1. Contaminants and natural toxicants. http://www.legislationgovau/Details/ F2013C00140.

Griboff J, Wunderlin DA, Monferran MV (2017) Metals, As and Se determination by inductively coupled plasma-mass spectrometry (ICP-MS) in edible fish collected from three eutrophic reservoirs. Their consumption represents a risk for human health? Microchem J 130:236-244

Guan QY, Zhao R, Pan NH, Wang FF, Yang YY, Luo HP (2019) Source apportionment of heavy metals in farmland soil of Wuwei, China: comparison of three receptor models. J Clean Prod 237:117792

Huang LM, Jin Q, Tandon P, Li AM, Shan AD, Du JJ (2018) Highresolution insight into the competitive adsorption of heavy metals on natural sediment by site energy distribution. Chemosphere 197: 411-419

Ip CCM, Li XD, Zhang G, Wong CSC, Zhang WL (2005) Heavy metal and $\mathrm{Pb}$ isotopic compositions of aquatic organisms in the Pearl River Estuary, South China. Environ Pollut 138:494-504

IRIS (Integrated Risk Information System by United States Environmental Protection Agency) (2018). https://www. cfpubepagov/ncea/iris/search/indexcfm?

Jafari A, Kamarehie B, Ghaderpoori M, Khoshnamvand N, Birjandi M (2018) The concentration data of heavy metals in Iranian grown and imported rice and human health hazard assessment. Data in Brief 16: 453-459

JETO (Japan External Trade Organization) (2011) Specifications and standards for foods, food additives, etc. In: under the Food Sanitation Act 2010

Joint FAO/WHO Expert Committee on Food Additives (2004) SixtyFirst Report of the Joint FAO/WHO Expert Committee on Food Additives. In: Evaluation of certain food additives and contaminants. World Health Organization, Geneva

Komarek M, Ettler V, Chrastny V, Mihaljevic M (2008) Lead isotopes in environmental sciences: A review. Environ Int 34:562-577

Leivas R, Laso J, Abejón R, Margallo M, Aldaco R (2020) Environmental assessment of food and beverage under a NEXUS Water-Energy-Climate approach: Application to the spirit drinks. Sci Total Environ 720:137576

Li PM, Gao XL (2014) Trace elements in major marketed marine bivalves from six northern coastal cities of China: Concentrations and risk assessment for human health. Ecotox Environ Safe 109: $1-9$

Liang LN, He B, Jiang GB, Chen DY, Yao ZW (2004) Evaluation of mollusks as biomonitors to investigate heavy metal contaminations along the Chinese Bohai Sea. Sci Total Environ 324:105-113

Liao Y-1, Yang J-y (2020) Microplastic serves as a potential vector for $\mathrm{Cr}$ in an in-vitro human digestive model. Sci Total Environ 703:134805
Loaiza I, De Troch M, De Boeck G (2018) Potential health risks via consumption of six edible shellfish species collected from Piura Peru. Ecotox Environ Safe 159:249-260

Lu J, Wu J, Zhang C, Zhang YX, Lin YC, Luo YM (2018) Occurrence, distribution, and ecological-health risks of selected antibiotics in coastal waters along the coastline of China. Sci Total Environ 644: 1469-1476

Lu J, Zhang Y, Wu J, Wang J, Zhang C, Lin Y (2019) Occurrence and spatial distribution of antibiotic resistance genes in the Bohai Sea and Yellow Sea areas, China. Environ Pollut 252:450-460

Lu J, Zhang Y, Wu J, Cai Y (2020) Fate of antibiotic resistance genes in reclaimed water reuse system with integrated membrane process. $\mathrm{J}$ Hazard Mater 382:121025

Mahjabin T, Mejia A, Blumsack S, Grady C (2020) Integrating embedded resources and network analysis to understand food-energywater nexus in the US. Sci Total Environ 709:136153

MARA (Ministry of Agriculture and Rural Affairs of the People's Republic of China) (2006) Pollution-Free Aquatic products of China (nonpredatory fish and products) - Contaminant and toxin limits (NY 5073-2006).

Phillips DL, Gregg JW (2003) Source partitioning using stable isotopes: coping with too many sources. Oecologia 136:261-269

Rai PK, Lee SS, Zhang M, Tsang YF, Kim KH (2019) Heavy metals in food crops: Health risks, fate, mechanisms, and management. Environ Int 125:365-385

Smidt SJ, Haacker EMK, Kendall AD, Deines JM, Pei LS, Cotterman KA, Li HY, Liu X, Basso B, Hyndman DW (2016) Complex water management in modern agriculture: Trends in the water-energyfood nexus over the High Plains Aquifer. Sci Total Environ 566: 988-1001

Storelli MM (2008) Potential human health risks from metals $(\mathrm{Hg}, \mathrm{Cd}$, and $\mathrm{Pb}$ ) and polychlorinated biphenyls (PCBs) via seafood consumption: Estimation of target hazard quotients (THQs) and toxic equivalents (TEQs). Food ChemToxicol 46:2782-2788

Storelli MM (2009) Intake of essential minerals and metals via consumption of seafood from the Mediterranean Sea. J Food Prot 72:11161120

Tan MG, Zhang GL, Li XL, Zhang YX, Yue WS, Chen JM, Wang YS, Li AG, Li Y, Zhang YM, Shan ZC (2006) Comprehensive study of lead pollution in Shanghai by multiple techniques. Anal Chem 78: 8044-8050

Tong Y, Zhu Z, Hao X, He L, He W, Chen J (2016) The study of lead content distribution in Chinese seafood and its oral bioavailability in mice. Environ Sci Pollut Res 23:1714-1721

Ullah AKMA, Maksud MA, Khan S, Lutfa LN, Quraishi SB (2017) Dietary intake of heavy metals from eight highly consumed species of cultured fish and possible human health risk implications in Bangladesh. Toxicol Rep 4:574-579

USEPA (U.S. Environmental Protection Agency) (2004) Risk Assessment Guidance for Superfund Volume I: Human Health Evaluation Manual (Part E, Supplemental Guidance for Dermal Risk Assessment). Office of Superfund Remediation and Technology Innovation, Washington, DC.

USEPA (U.S. Environmental Protection Agency) (2014) EPA Positive Matrix Factorization (PMF) 5.0 Fundamentals and User Guide. EPA/600/R-14/108.

USEPA (U.S. Environmental Protection Agency) (2016) Regional Screening Levels (RSLs) - user's guide. https://www.epagov/risk/ regional-screening-levels-rslsusers-guide- may-2016.

Varol M, Kaya GK, Alp A (2017) Heavy metal and arsenic concentrations in rainbow trout (Oncorhynchus mykiss) farmed in a dam reservoir on the Firat (Euphrates) River: Risk-based consumption advisories. Sci Total Environ 599:1288-1296

Wang W, Lu G (2017) Heavy Metals in Bivalve Mollusks. Chemical Contaminants \& Residues in Food Woodhead Publishing, pp 553594 
Wang XL, Sato T, Xing BS, Tao S (2005) Health risks of heavy metals to the general public in Tianjin, China via consumption of vegetables and fish. Sci Total Environ 350:28-37

Wen XH, Lu J, Wu J, Lin YC, Luo YM (2019) Influence of coastal groundwater salinization on the distribution and risks of heavy metals. Sci Total Environ 652:267-277

WHO (1982) Toxicological evaluation of certain food additives and contaminants (WHO Food Additives Series No. 17). World Health Organization, Geneva, pp 28-35

Wu J, Lu J, Luo YM, Duan DP, Zhang ZH, Wen XH, Min XY, Guo XY, Boman BJ (2016) An overview on the organic pollution around the Qinghai-Tibet plateau: The thought-provoking situation. Environ Int 97:264-272

Wu J, Lu J, Li L, Min X, Luo Y (2018) Pollution, ecological-health risks, and sources of heavy metals in soil of the northeastern QinghaiTibet Plateau. Chemosphere 201:234-242

Wu J, Lu J, Zhang C, Zhang YX, Lin YC, Xu J (2020) Pollution, sources, and risks of heavy metals in coastal waters of China. Hum Ecol Risk Assess 26:2011-2026

Xing WQ, Liu H, Banet T, Wang HS, Ippolito JA, Li LP (2020) Cadmium, copper, lead and zinc accumulation in wild plant species near a lead smelter. Ecotox Environ Safe 198:110683

Zhang W, Wang W (2012) Large-scale spatial and interspecies differences in trace elements and stable isotopes in marine wild fish from Chinese waters. J Hazard Mater 215-216:65-74
Zhang Y, Lu J, Wu J, Wang J, Luo Y (2020) Potential risks of microplastics combined with superbugs: Enrichment of antibiotic resistant bacteria on the surface of microplastics in mariculture system. Ecotox Environ Safe 187:109852

Zhao R, Yan SS, Liu M, Wang B, Hu D, Guo DB, Wang J, Xu WT, Fan C (2016) Seafood consumption among Chinese coastal residents and health risk assessment of heavy metals in seafood. Environ Sci Pollut Res 23:16834-16844

Zhong WJ, Zhang YF, Wu ZH, Yang RY, Chen XY, Yang J, Zhu LY (2018) Health risk assessment of heavy metals in freshwater fish in the central and eastern North China. Ecotox Environ Safe 157:343349

Zhu BQ, Lai NLS, Wai TC, Chan LL, Lam JCW, Lam PKS (2014) Changes of accumulation profiles from PBDEs to brominated and chlorinated alternatives in marine mammals from the South China Sea. Environ Int 66:65-70

Zhu Z, Tong Y, Tang W, Wu X, Wu Z (2017) Distribution of As, Cd, and $\mathrm{Pb}$ in seafood in Southern China and their oral bioavailability in mice. Environ Sci Pollut Res 24:3572-3581

Zurbrick CM, Gallon C, Flegal AR (2013) A new method for stable lead isotope extraction from seawater. Anal Chim Acta 800:29-35

Publisher's note Springer Nature remains neutral with regard to jurisdictional claims in published maps and institutional affiliations. 